\title{
Theatre of social justice
}

\author{
- Cite as: CMAJ 2020 June 8;192:E636-7. doi: 10.1503/cmaj.191438
}

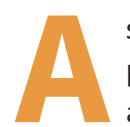

s I arrive to interview physicianplaywright Jeff Nisker, a woman asks him to please lock up when he leaves; he's the only one left in the office. His obstetrics-gynecology colleagues at London Health Sciences Centre, in Ontario, moved to another building months ago, but Nisker, whose plays and musicals have been performed at universities and professional meetings across Canada and in other countries, remains in a cramped office at the end of a deserted corridor. He retired from clinical practice a few years ago, and his teaching duties at Western's Schulich School of Medicine \& Dentistry are on hold while he recovers from prostate cancer, but he's here in a chair that supports his bad back, writing longhand about how the Cambie Clinic case, then being heard before the Supreme Court of British Columbia, will harm poor and disabled women by expanding private health care. "It's all social justice work," he says, sweeping his hand to the pad on his clipboard, the printed pages stacked next to his chair, and articles he's published in academic journals on a desk nearby.

Nisker joined the faculty at Western in the early 1980 s as a clinician-scientist, not a writer. But he's always been a voracious reader, and he credits a scornful teacher in grade nine with giving him a view of fiction as a way to understand the world. On English exams, she told him, "You quote huge chunks of things, but you have no idea what any of it means." Then she tasked him with discussing specific novels with her. To Kill a Mockingbird was an early assignment, and Atticus Finch became his hero. He decided to be a human rights lawyer, but his family argued that he had to take up the mantle for relatives murdered in the Holocaust who were physicians, so he went to medical school instead. He attended the University of Toronto, moved to London,

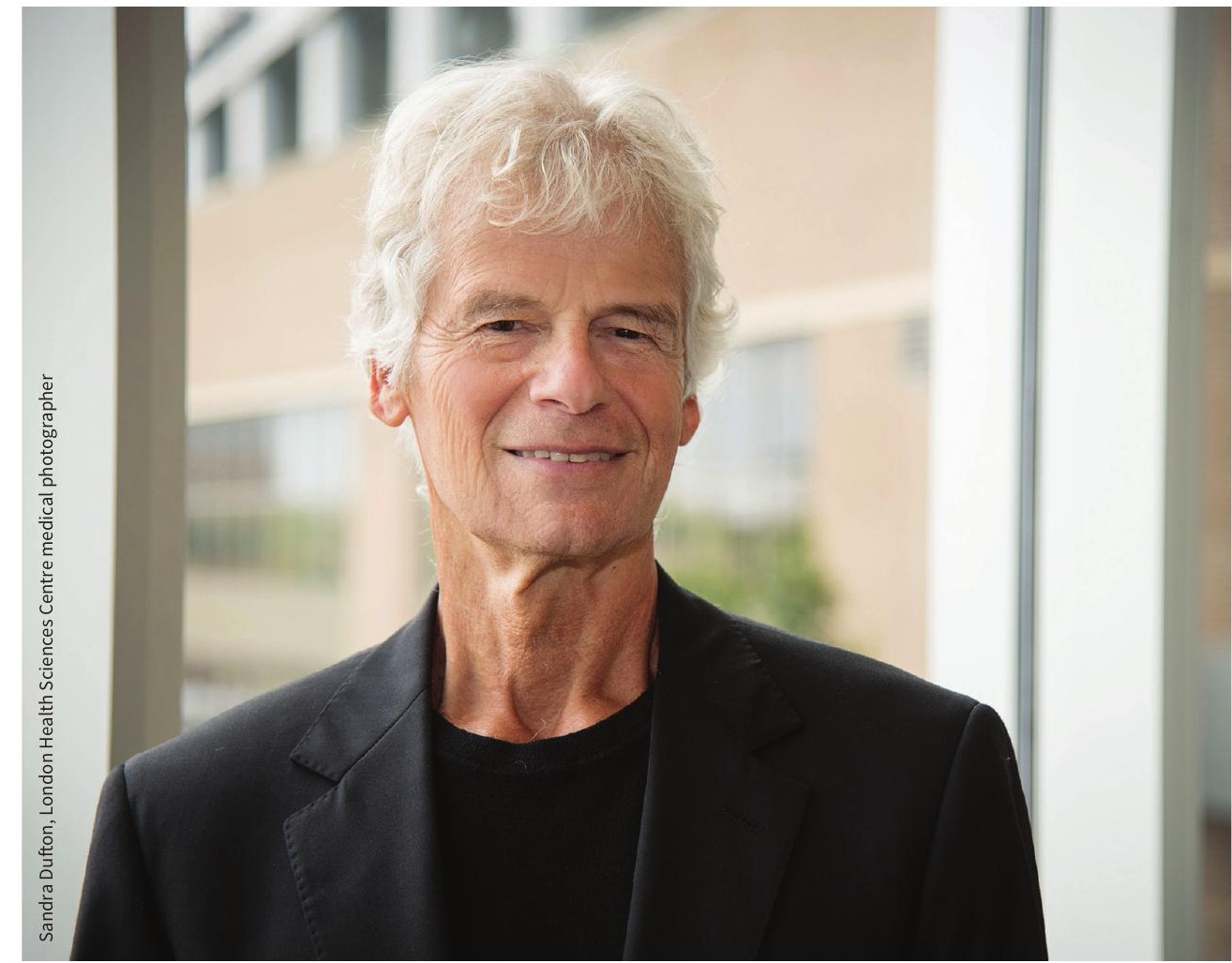

Playwright Dr. Jeff Nisker brings his passion for social justice to the stage.

Ontario, for residency, then started researching women's cancers in San Francisco before returning to Western.

He'd lost his mother and grandmother to breast cancer, so when the BRCA test became available to identify women at high risk for breast and ovarian cancer, he was appalled that Ontario and other provinces didn't offer it. He started writing and speaking on ethics in women's health and wasn't surprised when the dean asked him to take over bioethics teaching for the medical school. Certain that narrative was key to an ethics curriculum, he underpinned his classes with stories and movies and added an evening elective called "Monday night narratives," in which students could read or perform plays. He also wrote scripts and helped students write their own. Soon, half the class was attending the elective, and even those who couldn't make it knew to contact Nisker if they wanted to work on shows ("promotions, props, costumes, sets, acting, singing, drawing, writing or directing" were on one list alongside his phone number). On a typical Monday night in 1995, students performed scenes from Lisa Loomer's The Waiting Room, with one taking the part of an 18th-century Chinese woman whose bound feet were necrotic, and another playing a contemporary woman whose breast augmentation may have led to breast cancer. Afterward, Nisker and a scholar from the nearby Westminster Institute for Ethics and Human Values discussed society's expectations of physicians. ${ }^{1}$

As word of his interest in bioethics and theatre spread, he fielded unusual requests. 
In the mid-1990s, some doctors in emergency departments stigmatized patients they suspected of having AIDS by donning several pairs of gloves. When an AIDS advocate contacted Nisker about it, he said he could dramatize the problem if he met people with AIDS and heard about their experiences. "How else am I going to write the play?" he asked later. AIDS advocates in Vancouver arranged interviews in their community, and in 1997, AIDS Vancouver presented Nisker's play, with a cast of medical students and residents. He disdains that script today, calling its prose "purple," but it was his first show for an audience beyond his students, and the success fuelled him.

The following year, Orchids, his musical about embryo selection and eugenics, premiered at Western's theatre at Talbot College. Nisker had been studying preimplantation genetic diagnosis in the early 1990s, but he'd shut down his research after people called to volunteer for it, hoping it would help them preselect for male children. "You've got to take these stands," he said. Now, he'd returned to the subject of genetic diagnosis, interviewing a physician with Tourette syndrome, the heritable tic disorder, and writing a script about two women meeting at an infertility clinic, one who is living a full life with Tourette and one who wants to avoid having a child with Tourette.

"It takes some delicious chutzpah to want to create a musical about Tourette and IVF [in vitro fertilization]," said Stratford, Ontario-based performer Liza Balkan, who directed the touring version. And Nisker went further: he convinced the Canadian Institutes of Health Research and Health Canada to underwrite the tour, arguing that it would stimulate valuable discussion as the government developed regulations for genetic diagnosis. "Orchids touched people deeply," Balkan said. "They would come up afterwards crying, or stick around to talk about their own personal experiences." Ever the academic, Nisker and his research team taped and analyzed the after-performance discussions, concluding that theatre is an essential tool for engaging the public in health policy. ${ }^{2}$

He applied this truth to another drama that was challenging his abilities. In the 1990s, he met a woman with quadriplegia due to multiple sclerosis. Smoking, swearing and racing around the hospital in an electric wheelchair she operated with her chin, she urged Nisker to write about her, and he interviewed her several times. As they got to know one another, she added him to her list of emergency contacts; he introduced her to his sons and his Monday night students. In Calcedonies, the play he later wrote about her with Balkan as dramaturge, "Friend," the man in Nisker's role, discovers "Ruth" wants to write poetry, but she's been waiting years for her chair's joystick to be hooked up to her computer. Indignant, "Friend" calls the regional biomedical engineering unit and, in a moving passage of the play, an engineer calls back. ${ }^{3}$

\section{[Speaks very rapidly]}

I quickly plead Ruth's story, insisting that I'm not asking him to see Ruth ahead of someone else, rather to see her after hours, and would be happy to pay him at an overtime rate, and would consider it a personal favour.

\section{[Sheepishly]}

He jumps in before I embarrass myself further with, "Don't you think that every parent with financial means, whose child has cerebral palsy or a neuromuscular condition, offers to pay me to see their child after hours? They all want their child in computerized education, rather than falling farther and farther behind kids their age. Some parents without the money offer to "beg borrow or steal" to pay me. I stopped returning calls 2 years ago. The only reason I'm returning yours is because you're a physician.

An engineer eventually sees Ruth to take measurements, telling her to be patient until the computer linkage can be completed, but she dies from an infection before that happens.
Nisker and Balkan recruited Sheila Boyd, an actor disabled from birth by spina bifida, to take the part. Dancing and doing the moonwalk with an electric wheelchair donated for use in the show, Boyd left people in tears with her performance at the 2014 meeting of the Canadian Bioethics Society in Vancouver. In Montréal, McGill University students saw a portion of the play, then heard local experts discuss the legal and physical challenges of disability. Boyd would like to do the show in other cities, though Nisker isn't pushing for that. "I'm not a producer," he tells me. "I'm not a theatre person." He points out that he's primarily a scientist, with more than 200 published papers. Still, he'd like a broader audience for the "Ruth" story, so he turned the script into the novella Patiently Waiting For..., ${ }^{4}$ which he self-published and sells online and at medical conferences.

The book now on Nisker's clipboard includes tales of other women with difficult and desperate encounters with the health care system. It's a sunny fall day and he could be out paddling the Thames River in the kayak tied to the roof of his SUV in the hospital parking lot, but he's eager to complete it and file it as a factum with the Supreme Court of Canada - as the court hears the Cambie Clinic case. As he put it, "If the Supreme Court justices want to read Patiently Waiting For ..., they will get an idea."

\section{Miriam Shuchman MD}

Toronto, Ont.

\section{References}

1. Lin C. Yellow brick road bioethics. UWOMJ 1995;65:23.

2. Cox SM, Kazubowski-Houston M, Nisker J. Genetics on stage: public involvement in health policy development on pre-implantation genetic diagnosis. Soc Sci Med 2009;68:1472-80.

3. Nisker J. From Calcedonies to Orchids, plays promoting humanity in health policy. Toronto: Iguana Books; 2012:72-3.

4. Nisker J. Patiently waiting for ... Toronto: Iguana Books; 2016.

This article has been peer reviewed. 